\title{
Bitlis ili Mutki ilçesinde koyun keçi yetiştiren işletmelerin temel hayvan besleme bilgi düzeylerinin araştırılması*
}

\author{
Sinan Yıldırım¹, Halit İmik², Aytekin Günlü3 \\ ${ }^{1}$ Isparta Şarkikaraağaç İlçe Tarım ve Orman Müdürlüğ̈̈, Isparta/TÜRKIYYE \\ ${ }^{2}$ Atatürk Üniversitesi, Veteriner Fakültesi, Hayvan Besleme ve Beslenme Hastalıkları Anabilim Dalı, Erzurum/TÜRKIYE \\ ${ }_{3}^{3}$ Selçuk Üniversitesi, Veteriner Fakültesi, Hayvan Sağlığı Ekonomisi ve İşletmeciliği Anabilim Dalı, Konya/TÜRKIYE
}

Anahtar Kelimeler:
koyun
keçi
bakıım
besleme
üretim özellikleri

sheep

goat

maintenance

feeding

production characteristics

Geliş Tarihi : :28.02.2021

Kabul Tarihi : 02.06 .2021

Yavin Tarihi : 31.08 .2021

Makale Kodu : 888022

\section{Sorumlu Yazar:}

Halit IMIK

(halitimik60@hotmail.com)

ORCID

S. YILDIRIM

H. IMIK:

A. GÜNLÜ
:0000-0002-9106-6245

0000-0001-6933-2124

0000-0002-1989-8119

\section{ÖZ}

Türkiye'de son zamanlarda yașanan enflasyon artıșına bağlı olarak gıda fiyatlarının yükselmesi bitkisel ve hayvansal üretimi en çok tartışılan konular arasına almıştır. Özellikle kırmız et fiyatındaki artış ile başa çıkmak için kırmızı et ve et ürünleri ithalatının artması önemli bir sorundur. Bu sorunun çözümünde Özellikle Doğu Anadolu Bölgesi ve küçükbaș hayvan yetiștiriciliği öncelikli bir alandır. Bu çalıșmada Bitlis ili Mutki ilçesinde, koyun keçi yetiştiriciliği yapan yetiştiricilerin, sosyo ekonomik özellikleri ile hayvan besleme bilgi düzeyleri ortaya konularak rasyonel bir küçükbaş hayvan yetiștiriciliği için alınması gereken önlemlerin belirlenmesi amaçlanmıştır. Çalışmanın materyalini Bitlis ili Mutki ilçesinde koyun keçi yetiştiren işletmelerinden veri temin formları kullanılarak yüz yüze görüşme ile derlenen veriler kullanılmıştır. Elde edilen veriler bilgisayar ortamına aktarılarak SPSS.25 istatistik paket programı aracılığı ile analiz edilmiştir. Kategorik veriler Ki Kare testi ile analiz edilmiștir. Testin anlamlılık düzeyi için $\mathrm{p}<0,05$ değeri kabul edilmiştir. İlçede koyun yetiştiricilerinin iş tecrübeleri 31 y1l ve üzeri (\%48), ve asıl işlerinin koyun keçi yetiştiriciliği olduğu $(\% 92,7)$ belirlenmiştir. Üretim biçimi olarak göçer karakter taşıdığı anlașılmıștır. Kaba yem üretiminin \%68,7 oranında yapıldı̆̆ı, hayvanların kıșın \%53,4 oranında dış ortamda yemlendiği tespit edilmiştir. Yetersiz beslemenin bir göstergesi olarak kabul edilebilecek olan pikanın \%44,7 oranında bilindiği ve tespit edildiği anlaşılmıştır. Çalışmada eğitim düzeyi ile bilinçli yetiştiriciliğin göstergesi sayılabilecek uygulamaların önemli olduğu $(p<0,01)$ ve ișletme ölçeğinin büyümesinin bakım beslemenin iyileşmesine etkisinin önemli olduğu $(p<0,01)$ tespit edilmiştir. İlçede koyun keçi yetiştiriciliğinin önemli oranda geleneksel yöntemlerle yapıldığı, bakım besleme konusunda önemli eksikliklerin olduğu anlașılmıștır. Çalıșmada alınacak önlemler ile karlı ve verimli üretimin yapılabileceği anlaşılmıştır. İşletmelerde ölçeğin büyümesinin koyun keçi yetiştiriciliğini rasyonel hale getirebileceği sonucuna varılmıştır.

Investigation of basic animal nutrition knowledge levels of sheep and goat farming enterprises in Mutki district of Bitlis province

\begin{abstract}
The recent rise in inflation in Turkey resulting into increased prices of food products in crop and animal production is among the most hotly debated topics. Especially the increasing prices of red meat and the increased importation of red meat and meat products as a way of overcoming the increasing prices are a major problem. In solving this problem, especially the Eastern Anatolia Region and small ruminant farming is a priority area. This study was aimed at determining the measures to be taken for rational sheep and goat farming by revealing the socio-economic characteristics and animal nutrition knowledge levels of the sheep and goat farmers in the Mutki district of Bitlis province. The data for the study was collected using data collection forms by face-to-face interviews from sheep and goat enterprises in the Mutki district of Bitlis province. The data obtained was transferred to the computer and analysed using SPSS.25 statistical package program. Categorical data was analysed using the Chisquare test. A value of $\mathrm{p}<0.05$ was accepted for the significance level of the test. It was determined that the work experience of sheep farmers in the district was 31 years and above (48\%), and their main occupation was sheep and goat enterprise $(92.7 \%)$. It was understood that they had a nomadic character as a mode of production. It has been found out that the production of roughage is $68.7 \%$ and that the animals are fed at a rate of $53.4 \%$ outdoors in winter. It has been understood that as an indicator of insufficient feeding, $44.7 \%$ of pica cases were known and detected. In the study, it was determined that education level and practices that can be considered as an indicator of conscious enterprise are important $(p<0.01)$ and the growth of enterprise scale has significant effect on the improvement of maintenance feeding $(\mathrm{p}<0.01)$. It has been understood that sheep and goat enterprise in the district is

mostly carried out using traditional methods and there are important deficiencies in care and feeding. It is understood that profitable and efficient production can be made with the measures to be taken in the study. It has been concluded that increasing the scale in the enterprises can rationalize sheep and goat farming.
\end{abstract}

*Bu yüksek lisans tez çalışması Atatürk Üniversitesi Bilimsel Araş̧̧ıma Projeleri Koordinasyon Merkezi (BAP) tarafindan (TYL-2017-6011) desteklenmiș ve birinci yazarın yüksek lisans çalışmasında özetlenmiştir. 


\section{GİRİŞ}

Proteinler, canlı hücrenin kuru ağırlık üzerinden yaklaşık \%50'sini oluşturan kompleks yapıda makro moleküllerdir. Vücutta çok çeşitli biyolojik görevleri vardır. Hayvansal gıdalarda yer alan proteinler biyolojik değerleri açısından bitkisel kaynaklı proteinlere göre daha özellikli ve önceliklidirler. Dolayısıyla yeterli ve dengeli beslenme için öğünlerimizde mutlaka hayvansal kaynaklı besinlere yer verilmelidir. Hayvancilık sektörü bir yandan gida üretimi ve beslenme, diğer yandan istihdam, milli gelire katkı, sanayiye hammadde sağlama, kırsal kalkınma, kalkınma ve sanayileşme finansmanına katkı, kırsal alanda sermaye birikimi gida güvencesi ve güvenliği gibi konularda vazgeçilmez ve ikame edilemez özelliklere sahiptir. Dünya'da günlük toplam protein tüketim ortalamas1 $81,2 \mathrm{~g}$ olarak bildirilirken; bu değer Amerika Birleşik Devletleri’nde 110 g, Avrupa Birliği ülkelerinde 104 g, Türkiye'de ise 108 g'dır. Tüm bunlara ilaveten yaşanan pandemi gida üretimi ve hayvanc1lı sektörünü, gelecekte ülkelerin öncelikli alanları arasında taşıyacaktır.

Hayvansal üretimin en önemli belirteçlerinden birisi mevcut hayvan varlığının zaman içerisindeki değişimidir. Türkiye'nin 2013-2017 y1lları arasında sığır varlığ1 14.415.257 baş hayvandan 15.943.586 başa çıkmıştır. Bu değişim koyunda 29.284.247 baştan 33.677.636 baş koyuna, keçide ise 9.225 .548 baş keçiden 10.634.672 baş keçi varlığına ulaşılmıştır. İncelenen dönemde sığır, koyun, keçi ve manda varlığında sınırlı sayılacak bir artışın yaşandığı anlaşılmaktadır (1). Bu araştırmanın yapıldığ1 bölgeyi de içine alan Doğu Anadolu Bölgesi Türkiye'de hayvan varlı̆̆1 bakımından ön sıralarda yer almaktadır. Doğu Anadolu Bölgesi'nde bulunan hayvan varlığ1 Tablo 1'de özetlenmiștir (2). oranında azaldığı anlaşılmaktadır. Bir yandan hayvan sayısında yaşanan azalmalar diğer yandan verimlilik düzeyinde istenen iyileşmenin sağlanamaması nedeniyle artan hayvansal ürün fiyatlarını kontrol edebilmek için son yıllarda Türkiye'de sürekli ithalat gündeme gelmektedir. Örneğin 2018 yılının ilk 9 aylık döneminde canlı hayvan ithalatına 5.479.335.309 TL, karkas ete ise 886.728.191 TL olmak üzere toplam 6.366.063.500 TL'lik ithalat yapılmıştır. İthalat özellikle küçük ve orta ölçekli işletmelerin haksız rekabetle karşı karşıya kalmasına ve faaliyetlerini yürütmede zorlanmalarına ya da sektörden çekilmelerine ve hayvan sayısının iyice azalmasina neden olmaktadır (3).

Bu çalışmada, küçükbaş hayvancılığın yoğun olarak yapıldığ1 Bitlis İli Mutki ilçesinde küçükbaş hayvancılık ile uğraşan yetiştiricilerin temel hayvancilik ve hayvan besleme bilgi düzeyleri ile alışkanlıklarının belirlenmesi ve özellikle bölgede kırmızı et üretimi konusunda önemli potansiyele sahip olan küçükbaş hayvan yetiştiriciliğindeki temel problemler ile buna yönelik çözüm önerileri ortaya konulmaya çalışılmıştır.

\section{GEREÇ ve YÖNTEM}

Bu çalışmanın ana materyalini Bitlis İli Mutki İlçesinde koyun keçi yetiştiren işletmelerden yüz yüze anket ile elde edilen orijinal (birincil) veriler oluşturmaktadır. Bu amaçla proje kapsamında ulaşılan ve hazırlanan soru formlarını doldurmayı kabul eden tüm işletmeler araştırma kapsamına alınmış, toplam 150 adet üretici ile görüşme sağlanarak veriler derlenmiştir. Çalişmada Türkiye İstatistik Kurumu (TÜIK), Tarım ve Orman Bakanlığı ile diğer kurumların ikincil veri kaynakları, indekslerce taranan ve taranmayan yayınlardan, raporlardan ve tez ça-

Tablo 1. Doğu Anadolu Bölgesi hayvan varlığ1 (2014-2017)

Table 1. Animal existence in the Eastern Anatolia Region (2014-2017)

\begin{tabular}{lrrrrrrrr}
\hline & \multicolumn{2}{c}{$\mathbf{2 0 1 4}$} & \multicolumn{2}{c}{$\mathbf{2 0 1 5}$} & \multicolumn{2}{c}{$\mathbf{2 0 1 6}$} & \multicolumn{2}{c}{$\mathbf{2 0 1 7}$} \\
& Büyükbaş & Küçükbaş & Büyükbaş & Küçükbaş & Büyükbaş & Küçükbaş & Büyükbaş & Küçükbaş \\
\hline Erzurum & 655836 & 717843 & 641811 & 790467 & 650963 & 705953 & 731282 & 714229 \\
Erzincan & 101009 & 318148 & 95036 & 445071 & 93076 & 417704 & 114204 & 464999 \\
Bayburt & 67045 & 53283 & 85459 & 55282 & 87032 & 48200 & 78931 & 45317 \\
Ağr1 & 322307 & 1452572 & 327067 & 1387490 & 321892 & 1338007 & 352864 & 1494584 \\
Kars & 518722 & 499500 & 442575 & 567148 & 451368 & 563927 & 467362 & 481869 \\
Iğdır & 141986 & 628638 & 116150 & 882437 & 108160 & 903045 & 146451 & 974861 \\
Ardahan & 288118 & 48013 & 296564 & 51972 & 303619 & 72736 & 289815 & 60914 \\
Malatya & 134535 & 295580 & 130371 & 302199 & 136149 & 285991 & 171963 & 339987 \\
Elazı̆̆ & 146250 & 461686 & 142822 & 482589 & 148570 & 511232 & 159135 & 603377 \\
Bingö1 & 143784 & 485599 & 114954 & 545342 & 125089 & 575840 & 137512 & 504732 \\
Tunceli & 26169 & 432990 & 30360 & 419677 & 32535 & 412116 & 28516 & 336518 \\
Van & 163958 & 2691934 & 167388 & 2703581 & 162728 & 2658215 & 186099 & 2738054 \\
Muş & 285146 & 1085197 & 290521 & 984070 & 302215 & 1021142 & 306508 & 1049367 \\
Bitlis & 69267 & 878946 & 60839 & 701757 & 61743 & 718029 & 80504 & 594752 \\
Hakkâri & 36691 & 733515 & 34397 & 836415 & 34890 & 757597 & 44208 & 706351 \\
\hline Türkiye & 14345223 & 41485180 & 14127837 & 41924100 & 14222228 & 41329232 & 16105025 & 44312308 \\
\hline
\end{tabular}

Tablo 1 incelendiğinde Bitlis ilinde küçükbaş hayvan varlığının sabit ve belirli bir trend içermediği, yıllar içerisinde bazı dalgalanmaların yaşandı̆̆1 görülmektedir. 2014 y1l ile kiyaslandığında 2017 yılında hayvan sayısının \%26,5 lışmalarından da yararlanılmıştır. Elde edilen veriler bilgisayar ortamına aktarilarak SPSS.25 istatistik paket programı ile analiz edilmiştir. Kategorik veriler Ki Kare testi ile analiz edilmiştir. Testin anlamlılık düzeyi için $\mathrm{p}<0,05$ değeri kabul edilmiştir (4). 


\section{BULGULAR}

\section{İsletmeler Hakkènda Genel Bilgiler}

Araştırma kapsamında incelenen işletmelerin sahiplerine ait demografik ve sosyo-ekonomik veriler Tablo 2' de sunulmuştur. dönerek hayvanlarını ağılına koyarken, kimileri ise ev eșyaları ve hayvanlarıly yaylaya göçüp hayvanları haftalık tuz verme, aşılama ve süt sağım işlemleri haricinde meradan hiç getirmeden besleme yapmaktadırlar. Bazı işletme sahiplerinin de göçer olarak yani kış mevsiminde daha 1lıman bir iklime sahip, kar yağışıııın nispeten daha az olduğu Sïrt, Batman çevresine göç

Tablo 2. Araştırma kapsamına alınan işletmelere ait sosyo-ekonomik bulgular

Table 2. Socio-economic findings of the enterprises included in the study

\begin{tabular}{|c|c|c|c|}
\hline & & Say1 & Frekans $(\%)$ \\
\hline \multirow{5}{*}{ Yetiştiricilerin Eğitim Düzeyleri } & Okuryazar & 51 & 34,0 \\
\hline & İlkokul & 49 & 32,6 \\
\hline & Ortaokul & 22 & 14,7 \\
\hline & Lise & 6 & 4,0 \\
\hline & Okuryazar değil & 22 & 14,7 \\
\hline \multirow[t]{3}{*}{ Yetiştiricilerin Tecrübe Süresi } & 20 Yıl ve Aşağısı & 42 & 28,0 \\
\hline & 21-30 Y1l Aras1 & 36 & 24,0 \\
\hline & 31 Yll ve Üzeri & 72 & 48,0 \\
\hline \multirow[t]{3}{*}{ Kaç Yıldır Birliğe Üyesiniz? } & 6 Yil ve Aşağıs1 & 51 & 34,0 \\
\hline & 7-10 Yil Aras1 & 56 & 37,3 \\
\hline & 11 Yll ve Üzeri & 43 & 28,7 \\
\hline \multirow[t]{2}{*}{ Koyun-Keçi Yetiştiriciliği Asıl işiniz mi? } & Evet & 139 & 92,7 \\
\hline & Hayır & 11 & 7,3 \\
\hline \multirow{3}{*}{ Çoban Tedariki } & Kendisi & 110 & 73,3 \\
\hline & Ailesi & 39 & 26,0 \\
\hline & Dişarıdan & 1 & 0,7 \\
\hline
\end{tabular}

Tablo 2'den anlaşılacağ1 üzere ankete katılan işletme sahiplerinden \%34'ünün okur-yazar olduğu \%32,6'sının ilkokul mezunu olduğu anlaşılmıştır. Küçükbaş hayvan yetiştiriciliği konusundaki işletme sahiplerinin \% 48'inin 31 yll üzerinde tecrübeye sahip olduklar1-anlaşılmıştır. Koyun yetiştiricilerinin üretici örgütlerine üyeliklerinin son yıllarda artmaya başladığı ve üyelikte 11 yıl ve üzeri olanların oranının \%28,7 oranında olduğu anlaşılmıştır. Araştırma kapsamındaki işletmelerin $\% 92,7$ 'sinde asıl işin koyun keçi yetiştiriciliği olduğu tespit edilmiştir. Koyun keçi yetiştiriciliğinde sürü yönetim elemanı ya da çobanlık işlevi \% $\% 33,3$ oranında ișletme sahibi tarafından, \%26 oranında diğer aile fertleri ile $\% 0,7$ oranına ise dış kaynaklı olarak tedarik edildiği saptanmıştır.

Issletmelerin Bakım Besleme Bilgileri, Yem Bitkisi Üretimi, Barndirma, Besleme ve İsletme Ölçeğinin Bakım Beslemeye Etkisi

Araştırma kapsamında işletmelerin bakım besleme şekilleri de araştırılmış olup elde edilen sonuçlar ile araştırma kapsamına alınan ișletmelerde yem bitkisi üretimi, hayvanların yemleme ve sulama biçimleri ve bazı barındırma şartları Tablo 3 de verilmiştir.

Ayrıca hayvancıllk işletmelerinde işletme ölçeğinin artması ile bakım besleme konusunda bazı değişmelerin oluşması beklenmektedir. İşletme ölçeğinin büyümesi ile bakım beslemenin daha rasyonel olacağı beklentisini olușturmaktadır. Bu çalıșmada işletme ölçeği ile besleme düzeyi arasındaki ilişki incelenmiş ve elde edilen sonuçlar da Tablo 3'de sunulmuştur.

Araştırma kapsamındaki işletme sahiplerinin hayvanları için ot varlı̆̆ı, kar yağısıının durumu gibi nedenlere göre değișiklik göstermek suretiyle farklı ortamlarda besleme uygulamakta oldukları tespit edilmiştir. Kimi işletme sahipleri y1lın 12 ayı köylerinde kalıp, hayvanlarını köy merasında otlatıp akşam köyüne ederek, yaz mevsiminde nispeten daha serin olan kendi köylerine göç ederek yetiştiricilik yaptıkları anlaşılmıştır. Bu amaçla işletme sahiplerine 4 farklı soru yöneltilmiştir.

Tablo 3'deki verilere göre; köy ve civarında kalan işletme sahiplerinden 6 ay ve daha fazla süre ile kalanlarnn oran1 \%70, 1 ve 3 ay süre ile kalanların oranı $\% 2,7,2$ ay boyunca kalanların oranı ise $\% 13,3$ olarak hesaplanmıştır. Yetiştiricilerden hiçbirinin 4 veya 5 ay boyunca köy ve civarında kalmadığı görülmüştür. Köy ve civarında hiç kalmayanların oranı ise $\% 11,3$ olarak belirlenmiştir.

Sürekli olarak ağılda 3 ay süreyle besleme yapanların oranı $\% 8$ olarak hesaplanmış, 4 ay boyunca sürekli ağılda besleme yapanların oranı $\% 76,7$ gibi yüksek bir oran belirlenmiştir. Burada orandaki yükseklik hayvanlarını kış mevsiminde göçer olarak yetiştiricilik yapmayıp kış mevsimi boyunca hayvanlarına ağılda bakım besleme yapan işletme sahiplerinden kaynaklandı$\breve{g} 1$ anlaşılmaktadır. 5 ay ve üzeri sürekli ağılda besleme yapan işletme oranı \% $\%, 6$ ay ve üzeri sürekli ağılda besleme yapanlarnn oran1 $\% 1,3$ son olarak ağılda sürekli besleme yapmayanların oran1 $\% 10$ olarak belirlenmiştir.

Yaylada 4 ay süre ile kalan işletme oranı $\% 0,7,5$ ay süre ile kalanların oranı \%5,3, 6 ay ve üzerinde yaylada kalan işletme oranı ise \% 24 olarak belirlenmiştir. Yaylada kalmayanların ora$\mathrm{n} 1$ ise $\% 70$ olarak hesaplanmıştır.

Göçer yetiştirici olarak gittiği yerde 5 ay süre ile kalanların oran1 $\% 0,7,6$ ay ve üzeri kalarak yetiştiriciliğine devam edenlerin oranı $\% 9,3$, göçer yetiştirici olarak hiç yetiştiricilik yapmayanların oranı ise $\% 90$ olarak belirlenmiştir. 
Tablo 3. İşletmelerin hayvan besleme ve yem bitkisi üretimine ilişkin bulgular

Table 3. Findings on animal nutrition and forage crop production by enterprises

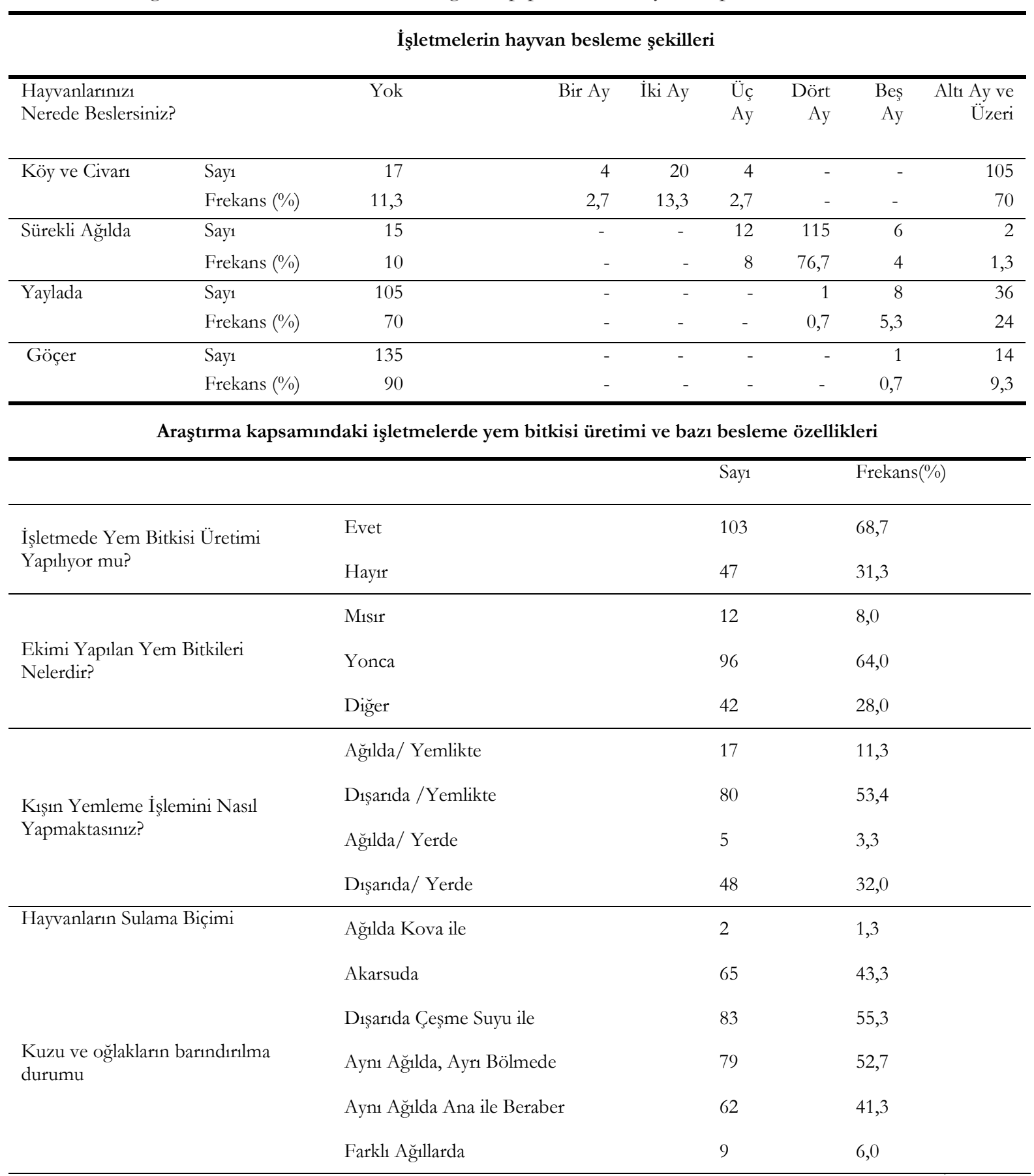

İşletme ölçeklerinin hayvanlara konsantre yem verilmesi üzerine etkisi

\begin{tabular}{|c|c|c|c|c|c|c|c|c|c|}
\hline & & \multicolumn{6}{|c|}{ İşletme Ölçeği Nedir? } & \multirow{3}{*}{$x^{2}$} & \multirow{3}{*}{$\mathrm{P}$} \\
\hline & & \multicolumn{2}{|c|}{ Küçük } & \multicolumn{2}{|c|}{ Orta } & \multicolumn{2}{|c|}{ Büyük } & & \\
\hline & & Say1 & Yüzde & Say1 & Yüzde & Say1 & Yüzde & & \\
\hline Hayvanlarınıza Konsantre/Tane & Evet & 0 & 0 & 6 & 12 & 18 & 24 & & \\
\hline Yem Veriyor Musunuz? & $\underline{\text { Hayır }}$ & $\underline{24}$ & $\underline{100}$ & $\underline{46}$ & $\underline{88}$ & $\underline{56}$ & $\underline{76}$ & 9,157 & 0,010 \\
\hline Toplam & & 24 & 100 & 52 & 100 & 74 & 100 & & \\
\hline
\end{tabular}


Tablo 3 incelendiğinde ișletme sahiplerinin \%68,7 sinin yem bitkisi üretimi yaptığı belirlenmiștir. Yem bitkisi üretimi yapmayanlar yeterince arazileri olmadığı için kışlık kaba yem ihtiyacını ya satın alarak ya da dağdan ot toplayarak ve meşe dallarını budayarak yeşil olarak kuruttukları ve çilo ismini verdikleri meşe dalı kurusu ile besleme yaptıkları belirlenmiştir. Yem bitkisi olarak yetiştiricilerin \%8'lik kısmının mısır, \%64' lük kısmının yonca, \%28'lik kısmının ise (dar1 vb.) diğer yem bitkilerini ektikleri belirlenmiştir. Hayvanların barındırıldıklar1 ağılların geleneksel yöntemlerle inşa edilmiş taş veya kerpiç duvar ile ahşap çatılı toprak zemin yapılı, kimilerinde ahşaptan yapma sabit yemliğin olduğu kimilerinde ise yemleme işlemi için sabit bir yemliğin olmadığ1, sulama işlemi için suluk ekipmanının ise hemen hemen hiçbir işletmede bulunmadı̆̆1 ağıllardan oluştuğu gözlenmiştir. İşletmelerin \%11,3’ü kışın yemleme işlemini ağılda yemlikte, $\% 53,4$ 'ünün ağılın dişarısında yemlikte, $\% 3,3$ 'ünün ağılda yerde (zeminde) ve son olarak \% 32 'sinin ise dişarıda yerde (zeminde) yaptıkları tespit edilmiştir. Koyunlar ağırlıklı olarak akarsu $(\% 43,3)$ ve çeşme suyu $(\% 55,3)$ ile sürü halinde su ihtiyaçları karşılandığı belirlenmiştir. İlçede işletmelerde \%52,7 oranında kuzu/oğlaklarını aynı ağılda analarından ayrı bir şekilde barındırdığ1, \%41,3 oranında aynı ağılda anaları ile bir arada barındırdığı, \%6'sı ise farklı ağıllarda barındırdıkları belirlenmiştir. Küçükbaş yetiştiriciliğinde önemeli olan ilave yemleme (flushing) incelenen işletmelerde önemli oranda yapılmadığ1 $(\% 97,8)$ yapanların oranı sadece $\% 1,3$ olarak belirlenmiştir. Yetiştiricilerin mera veya yem değişiklikleri durumlarında yapmış oldukları enterotoksemi aşısını yaptırma durumuna karşı vermiş oldukları cevap hiç yaptırmayan $\% 2$, yılda bir defa yaptıran $\% 27,3$ ve yılda 2 defa yaptıranların oranı ise $\% 70,7$ olarak belirlenmiştir.
Tablo 3 işletme ölçeği açısından incelendiğinde işletme ölçeği arttıkça hayvanlara konsantre yem verme eğiliminin önemeli oranda arttı̆̆1 anlaşılmıştır ( $\mathrm{p}<0,05)$. Küçük ölçekli işletme sahiplerinin hiç birinin, orta ölçekli işletme sahiplerinin \%12'sinin, büyük ölçekli işletme sahiplerinin ise \%24'lük kısmının hayvanlarına konsantre/tane yem verdikleri anlaşılmıştır. Her ne kadar büyük ölçekli işletmelerde bile konsantre yem verip vermediği sorusuna hayır diyenlerin oranı \%76 ile daha fazla olsa da hayvanlarina konsantre/tane yem verenlerin oranı küçük ölçekli işletmelere göre daha fazla olduğu anlaşılmaktadır. Büyük ölçekli işletmelerde hayvanlara konsantre/tane yem verme eğiliminin küçük ve orta ölçekli işletmelere göre fazla olması işletme ölçeğinin büyümesiyle birlikte elde edilen gelirin de büyümesine bağlamak mümkündür

İsletmelerin Vitamin-Mineral Uygulama Durumu ile Ögrenim Durumlarnm Vitamin E ve Selenyum Takviyesi Yapma Üzerine Etkisi

Sağlıklı ve karlı bir yetiştiricilikte yapılması gereken uygulamalardan biri de vitamin E ve selenyum takviyesidir. İlçede incelenen işletmelerde bunun uygulanma durumu ile işletme sahiplerinin ögrrenim durumunun hayvanları tedavi etme şekli üzerine etkisini gösteren veriler Tablo 4'de verilmiştir.

Tablo 4. İşletmelerin vitamin $\mathrm{E}$ ve selenyum uygulamalarına ilişkin bulgular

Table 4. Findings on vitamin $\mathrm{E}$ and selenium applications of enterprises

\begin{tabular}{|c|c|c|c|c|c|c|c|}
\hline \multicolumn{8}{|c|}{ İşletmelerde Vit-E ve selenyum uygulama durumu } \\
\hline \multicolumn{3}{|c|}{$\begin{array}{c}\text { Hayvanlarınıza Vitamin E-Selenyum Takviyesi Yapıyor } \\
\text { Musunuz? }\end{array}$} & \multicolumn{2}{|c|}{ Say1 } & \multicolumn{3}{|c|}{ Frekans $(\%)$} \\
\hline & \multicolumn{2}{|c|}{ Evet } & \multicolumn{2}{|c|}{81} & \multicolumn{3}{|c|}{54,0} \\
\hline & \multicolumn{2}{|c|}{ Hayır } & \multicolumn{2}{|c|}{69} & \multicolumn{3}{|c|}{46,0} \\
\hline \multicolumn{8}{|c|}{ İşletme sahiplerinin öğrenim durumlarının Vit-E ve Selenyum takviyesi yapma üzerine etkisi } \\
\hline \multicolumn{5}{|c|}{$\begin{array}{c}\text { Yeni Doğan Kuzulara/Oğlaklara Vitamin E ve Selenyum Takviyesi } \\
\text { Yapiyor Musunuz? }\end{array}$} & Toplam & $x^{2}$ & $\mathrm{P}$ \\
\hline \multirow{2}{*}{ Öğrenim Durumu } & \multicolumn{2}{|c|}{ Evet } & \multicolumn{2}{|c|}{ Hayır } & & & \\
\hline & Say1 & Yüzde & Say1 & Yüzde & & & \\
\hline Okuryazar & 33 & 65 & 18 & 35 & 51 & & \\
\hline İlkokul & 29 & 59 & 20 & 41 & 49 & & \\
\hline Ortaokul & 12 & 54 & 10 & 46 & 22 & 12579 & 0,014 \\
\hline Lise & 2 & 33 & 4 & 67 & 6 & & \\
\hline Okur yazar değil & 5 & 23 & 17 & 77 & 22 & & \\
\hline
\end{tabular}


Tablo 4 incelendiğinde anket kapsamındaki işletme sahiplerinden \%54'ünün hayvanlarına Vitamin E ve Selenyum takviyesi yaptığı, \%46'sının ise yapmadığı belirlenmiştir. Araştırma kapsamında okuryazar olmayan işletme sahiplerinden söz konusu uygulamay1 yapanların oranı $\% 23$, yapmayanların oranı ise $\% 77$ olarak belirlenmiştir. Okuryazar işletme sahiplerinden \%65'i Vitamin E ve Selenyum takviyesi yaparken, \%35'i ise yapmadıklarını bildirmişlerdir. Ortaokul mezunu işletme sahiplerinde ise uygulamay1 yapanların oran1 $\% 54$ yapmayanlarin oranı ise \%46 olarak belirlenmiştir. Lise mezunu işletme sahiplerinden, Vitamin E ve Selenyum uygulaması yapanların oranı $\% 33$ yapmayanların oranı ise $\% 67$ olarak hesaplanmıştır. Bu sonuçlara göre öğrenim durumu ile Vitamin E-Selenyum uygulaması yapma arasında anlamlı bir fark olduğu $(p<0,05)$ ve eğitimli işletme sahiplerinin hiç eğitim almamış işletme sahiplerine göre Vitamin E ve Selenyum uygulaması yapma konusunda daha istekli oldukları anlaşılmıştır.

\section{Pika Hastalı̆g ve Issletmelerdeki Durumu}

Bakım besleme koşullarının yetersizliği, vitamin ve mineral takviyesinin yapılmayışı gibi birtakım nedenlerden ötürü hayvanlarda pika yani yabanc1 cisim (k1l, yün, toprak vs.) yeme rahatsızlığı görülür. Çalışmada hayvanlarda duvarları yalama, altlıklarını yeme gibi davranışların olup olmadığı var ise yetiştiricilerin sebebi konusunda bilgilerinin olup olmadiğ1 ve bu durumu engellemek adına ne yaptıkları ortaya konulmaya çalışılmıştır. Elde edilen sonuçlar Tablo 5'de sunulmuştur.
İşletme sahiplerinden \%44,7'si hayvanlarında pika rahatsızlığının olduğunu, \%37,3’ü pika rahatsızlığ1 olmadığını belirtmişlerdir. İşletmelerin \%18'inin ise hayvanlarında pika olup olmadığını bilmediği ortaya konulmuştur. Pikanın önlenmesi amacıyla işletmelerde alınan önlemlere ait bulgular incelendiğinde, pika rahatsızlı̆̆ının önlenmesi konusunda bölgede en yaygin olarak yapılan uygulama \%25,3 oranında kaya tuzu kullanımının olduğu anlaşılmıştır. Hiçbir şey yapmayanların oranı $\% 17,3$; herhangi bir cevap vermeyenlerin oran 1 ise $\% 46,7$ olarak tespit edilmiştir.

\section{İsletmelerde Koruyucu Aşılama Uygulama}

Çalışma kapsamında koyun keçi yetiştiriciliğinde koruyucu sağlık hizmetlerinin hem işletme sonuçları üzerine olumlu katkısı hem de üretici bilgi düzeylerinin bir belirleyicisi olarak aşılama durumları incelenmiş elde edilen sonuçlar Tablo 6 olarak sunulmuştur.

Tablo 5. Pika hastalığ1 ve işletmelerdeki durumu

Table 5. Pica disease and its status in enterprises

İşletmelerde pika (duvar yalama, yataklık yeme) durumu

\begin{tabular}{|c|c|c|}
\hline $\begin{array}{l}\text { Hayvanlarınızda duvarları yalama, yataklıkları yeme gibi davranışlar } \\
\text { var mı? }\end{array}$ & Say1 & Frekans $(\%)$ \\
\hline Evet & 67 & 44,7 \\
\hline Hayır & 56 & 37,3 \\
\hline Bilinmiyor & 27 & 18,0 \\
\hline Toplam & 150 & 100,0 \\
\hline \multicolumn{3}{|c|}{ İşletmelerde pikayı önlemek için yaygın uygulamalar } \\
\hline $\begin{array}{c}\text { Duvar yalama yataklık yeme davranışlarını önlemek için ne } \\
\text { yapıyorsunuz? }\end{array}$ & Say1 & Frekans $(\%)$ \\
\hline Cevap Boş & 70 & 46,7 \\
\hline Yalama Taşı Kullanıyorum & 1 & 0,7 \\
\hline Kaya Tuzu Veriyorum & 38 & 25,3 \\
\hline Vitamin Enj. ve Tablet Uygulaması Yapıyorum & 15 & 10,0 \\
\hline Hiçbir Şey Yapmıyorum & 26 & 17,3 \\
\hline Toplam & 150 & 100,0 \\
\hline
\end{tabular}


Tablo 6. İşletmelerde koruyucu aşılama uygulama sıklıkları

Table 6. Preventive vaccination application frequencies in enterprises

\begin{tabular}{|c|c|c|c|c|}
\hline Aş1 & & Hiç & Yilda 1 Defa & Yilda 2 Defa \\
\hline \multirow{2}{*}{ Enterotoksemi } & Say1 & 3 & 41 & 106 \\
\hline & Frekans (\%) & 2 & 27,3 & 70,7 \\
\hline \multirow{2}{*}{ Brusella } & Say1 & 99 & 51 & 0 \\
\hline & Frekans $(\%)$ & 66 & 34 & 0 \\
\hline \multirow{2}{*}{ Keçi Ciğer Ağrısı } & Say1 & 99 & 51 & 0 \\
\hline & Frekans (\%) & 66 & 34 & 0 \\
\hline \multirow{2}{*}{ Septisemi } & Say1 & 150 & 0 & 0 \\
\hline & Frekans $(\%)$ & 100 & 0 & 0 \\
\hline \multirow{2}{*}{ Agalaksi } & Say1 & 134 & 16 & 0 \\
\hline & Frekans (\%) & 89,3 & 10,7 & 0 \\
\hline \multirow{2}{*}{ Koyun-Keçi Veba (PPR) } & Say1 & 10 & 140 & 0 \\
\hline & Frekans $(\%)$ & 6,7 & 93,3 & 0 \\
\hline \multirow{2}{*}{ Çiçek } & Say1 & 123 & 27 & 0 \\
\hline & Frekans $(\%)$ & 82 & 18 & 0 \\
\hline \multirow{2}{*}{ Ektima } & Sayı & 150 & 0 & 0 \\
\hline & Frekans (\%) & 100 & 0 & 0 \\
\hline Şap & Say1 & 21 & 74 & 55 \\
\hline
\end{tabular}

Araştırma kapsamındaki işletmelerde verimliliğe ve işletme ekonomik performansına önemli etkileri olacak koruyucu sağlık uygulamalarının başında aşılama çalışmaları gelmektedir. Tablo 6 incelendiğinde genel olarak beklenen planlı uygulamanın olmadığı anlaşılmaktadır. Şap aşısı genel olarak yılda bir defa yapıldı̆̆ı, işletmelerinin tamamında septisemi ve ektima aşılarının hiç yapılmadığı anlaşılmaktadır.

\section{TARTIŞMA}

Araştırma kapsamında incelenen işletme sahiplerinden \%34'ünün okur-yazar, \%32,7'sinin ilkokul mezunu, \%14,7' sinin ortaokul mezunu, \%4'ünün lise mezunu olduğu belirlenmiştir. \%14,7’ lik bölümünün ise okuma yazmayı hiç bilmediği saptanmıştır. Bursa ili Uludağ yöresinde yapılan benzer bir çalışmada hayvancilıkla uğraşan kişilerin \%91,7'sinin ilkokul mezunu veya ilkokuldan terk, \%8,3'ünün ise lise mezunu olduğunu bildirilmiştir (5). Gaziantep ilinde 2018 yllında yürütülen benzer bir çalışmada, incelenen 91 keçi yetiştiricisinden 77'sinin ilkokul, 10'unun ortaokul, 2'sinin lise, 1'inin ise yükseköğrenim mezunu olduğu tespit edildiğini, bu soruya 1 yetiştiricinin ise cevap vermediğini ayrıca 92 koyun yetiştiricisinden 61'inin ilkokul, 13'ünün ortaokul, 8'inin lise, 5'inin ise yükseköğretim mezunu olduğu tespit edildiğini 5 yetiştiricinin ise bu soruya cevap vermek istemediği bildirilmiștir (6). Bu bağlamda eğitim durumları bakımından değerlendirildiğinde koyun keçi yetiştiriciliği yapan işletme sahiplerinin daha önce gerçekleştirilen çalışmalarla benzerlik gösterdiği ve sektörde eğitim düzeyinin yetersiz olduğu anlaşılmaktadır $(5,6)$.

Koyun-keçi yetiştiricilerinin eğitim durumlarının düşük seviyede olması hayvan bakım ve beslemesinde yeni bilgileri kabullenmede bir takım zorluklara neden olmaktadır. Uygulanması Tarım ve Orman Bakanlığ tarafindan zorunlu kılınmış aşıları (Koyun-Keçi Veba Aşısı) bile yaptırıp yaptırmama konusunda tereddüt göstermeleri, uygulanacak bazı vitamin ve minerallerle veya flushing yöntemi ile döl veriminin arttırlabileceği gerçeğini önemsememeleri, yalnızca kaba yem kullanarak daha ekonomik hayvancılık yaptıkları inanışı gibi durumlar yukarıda bahsedilen zorluklardan yalnızca bir kaçına örnek olarak gösterilebilir.
Yapılan çalışmada Bitlis ili Mutki ilçesindeki koyun keçi yetiştiricilerinin yetiştiricilik tecrübeleri ve sürekliliği incelenmiş, 20 yıldan daha az süredir küçükbaş hayvan yetiştiriciliği yapan işletmelerin oranı $\% 28 ; 21-30$ yıl arası küçükbaş hayvan yetiştiriciliği yapanların oranı \%24 olarak belirlenmiştir. 31 yllın üzerinde küçükbaş hayvan yetiştiriciliği yapan işletmelerin oranı \%48 olarak hesaplanmıştır. Yine yapılan bir çalışmada keçi yetiştiriciliği ile uğraşanların \%44,85'nin 1 ile 20 yil arasında, \%40.02'sinin 21 ile 40 yll arasinda, \%15,2'sinin de 41 yll ve üzeri bir süredir bu işle uğraştıkları bildirmiştir (7). Yapılan başka bir çalışmaya katılanların \% 73 'ünün 20 yıldan fazla süredir hayvancılık yaptığını, \%16,7'sinin 16-20 yıldır, \%10'unun ise 6-10 yıldır hayvancılıkla uğraştığını bildirmiştir (5). Çalışmada elde edilen bulgular Türkiye'de farklı coğrafi bölgelerde de olsa küçükbaş hayvan yetiştiriciliğinin önemli oranda geleneksel bir meslek olarak sürdürüldüğü anlaşılmaktadır. Koyu yetiştiriciliğin karlı ve verimli bir yapıya kavuşturulması ve bilinç düzeyini artırmaya yönelik çalısmaların artırılması sürdürülebilirlik ve gelecek nesillerin yetiştiriciliğe ilgisinin artmasina neden olabilir.

Küçükbaş hayvan yetiştiriciliğinde özellikle sürü yönetim elemanı (çoban) bulamamanın sektörün en temel problemi gibi olduğu ileri sürülerek buna yönelik önlemler alınmaktadır. Çalışmada işletmelerdeki sürü yönetim elemanı ya da çoban işlevini işletme sahibinin yürüttüğü işletmelerin oranı $\% 73,3$; aileden birileri diyenlerin oranının \%26 olduğu ortaya konulmuştur. Ücret karşlloğı çoban tutanların oranı ise yalnızca \%0,7 olduğu saptanmıştır. Yapılan başka bir çalışmada Yüksekovalı küçükbaş hayvan yetiştiricilerinin ancak \%2'sinin aile fertlerinden çoban ihtiyaçlarını karşılarken \%98'inin ücretli olarak çoban tuttuklarını belirtilmiştir (8). Elde edilen bulgular ve literatür bilgileri birlikte değerlendirildiğinde sektörün sürdürülebilirliği bakımından bu noktanın önemli olduğu ancak sorunun çözümünün lokal ve bölgesel adımlar atılması gerektirdiği anlaşılmıştır.

Çalışma kapsamında işletme sahiplerine koç/teke katımından önce ek yemleme (flushing) yapıp yapmadıkları rasyonel yetiştirme bilgisinin önemli bir kriteri olarak algılanarak araş- 
tırılmıştır. Çalışmada, işletme sahiplerinden \%1,3'ünün flushing uygulaması yaptığını, \%98,7'sinin ise flushing uygulaması yapmadığını belirlenmiştir. Yapılan bir başka çalışmada keçi işletmelerinin \%44,85'inin tamamen makilik alanlardan yararlandığını, \%67,27'sinin ek yemleme (flushing) yaptığını, \%32,73'ünde ek yemleme yapılmadığını, \%3,64'ünde y1l boyunca ağılda besleme yapıldı̆̆ı belirlenmiştir. Ayrıca yetiştiricilerin \%75,15'inin teke katımı öncesi yemleme yapmadı̆̆ını, \%24,85'inin de katım öncesi ek yemleme yaptığın1, \%35,76's1nın doğum sonrası ek yemleme yapmadığını tespit etmiştir (7). Elde edilen bu bulgu ilçede yetiştiricilerin temel bakım besleme konusunda oldukça yetersiz oldukları en temel bakım besleme uygulamalarından başlanarak yapılacak eğitim çalışmalarının işletme teknik parametreleri ve ekonomik sonuçlarının iyileştirme potansiyelinin olduğunu ortaya koymaktadır.

Van ilinde yapılan bir çalışmada, düzenli sağlık kontrollerinin işletmelerin büyük bir çoğunluğunda $(\% 54,8)$ yapılmadı̆̆1nı bildirmiştir. Ayrıca işletmelerin sadece \%45,2'sinin düzenli sağlık kontrolü yaptırdıklarını, sağlık hizmeti alma konusunda yetiştiricilerde duyarlılık söz konusu olmadığını, bunun sebebinin ise yüksek hayvan sağlı̆̆ı maliyetinin olduğunu belirtmiştir. Araştırma kapsamında incelenen işletmelerin \%79,8'inde, Tarım Bakanlığg’nın uyguladığı aşılama programından faydalanıldığ1 ve diğer aşıları özellikle enterotoksemi ve çiçek aşılarının yetiştiriciler tarafından satın alınarak kendileri tarafından yapıldığı belirtilmiştir (9). Yetiştiricilerin ancak bir anda çok sayıda hayvanı hastalandığında veteriner hekimlik hizmeti aldıklarını, aksi halde kendi imkânları ile aldıkları antibiyotiklerle tedavi yoluna gittiklerini tespit ettiğini bildirmiştir.

Burdur ilinde gerçekleştirilen çalışmada işletmelerin yılda en az bir çeşit koruyucu aşı yaptırdıklarını, koyunculuk işletmelerinde enterotoksemi, çiçek, şap, brusella aşılarından hepsini yaptıranların \%64,9, keçicilik işletmelerinde aşılanın hepsini yaptıranların \%13,6 olduğunu tespit etmiş, koyunculuk işletmelerinin \%85,1'inin ve keçicilik işletmelerinin \%95'inin sürekli olarak bir veteriner hekimle çalışmadıkları, sadece aşılama ve hastalık çıkışı olduğunda veteriner hekime başvurdukları bildirilmiştir (10).

Bitlis ili Mutki ilçesinde 150 işletmeyle yapmış olduğumuz çalışmada yer alan aşılama ve hastalık tedavileri konusunda izlenen yolun ne şekilde olduğunu araştırdığımız bölümde elde ettiğimiz sonuçlar, benzer çalışmalarla örtüşmektedir (7-10). Hem Bitlis ili Mutki ilçesinde hem de Van, Çanakkale, Burdur ve Isparta gibi illerle birlikte tüm Türkiye'de yetiştiricilerimizde hayvanlara önemli verim kayıpları yaşatan hastalıklara karşı aşılama konusundaki hassasiyetin istenilen seviyede olmamasinin nedenleri genel olarak; maddiyat, iş gücü zorluğu, bilgisizlik ve hayvancılıkta koruyucu hekimlik noktasındaki farkındalığın yetersiz olması şeklinde sıralanabilir.

$\mathrm{Bu}$ anket çalışmasında ankete katılan yetiştiricilerinden \%54'ü sürülerine vitamin $\mathrm{E}$ ve selenyum takviyesi uygularken \%46'sının uygulamadığı görülmektedir. Yabancı madde yeme hastalığ1 olarak bilinen pika hastalığ1 ile ilgili soruda ise yetiştiricilerin \%44,7'si bu hastalığ1n görüldüğünü, \%37,3’ünün ise görülmediği ve \%18'inin ise bu durumla ilgili soruya bilgisinin olmadığını bildirmiştir. Yabancı madde yeme hastalığına karşı ne yapıldığ1 sorulduğunda ankete katılan yetiştiricilerden \%70’i bu soruya cevap vermez iken, \%0,7'si yalama taşı kullandığını, \%25,3’ünün kaya tuzu verildiğini, \%10'nun vitamin enjeksiyonu ve tablet uyguladığını, \%17,3'ünün ise hiçbir şey yapmadığ1$\mathrm{n}$ bildirmişlerdir. Yapılan bu anket çalışmasında ankete katılan yetiştiricilerin önemli kısmının hayvanların beslenmesinde yeterli düzeyde veya hiç vitamin ve mineral katkısı kullanmadıkları tespit edilmiştir. Bu durumun ise ciddi anlamda hayvanların verim performanslarını olumsuz olarak etkileyeceği görülmektedir.

Yetiştiriciler kış sezonun bitmesi baharın gelmesi ile meraya çıkarmadan (yaklaşık 15-21 gün önce) ve yine özellikle buğday, arpa gibi ürünlerin hasat edilmesinden sonra hayvanlar1n1 bu alanları mera olarak kullanmadan önce enterotoksemi aşısı uygulayarak ani yem değişikliğinden ileri gelecek kayıpları önledikleri görülmektedir. Bu tür ani yem değișiklikleri hayvanlarin sindirim sisteminde hizlı fermantasyona maruz bırakır en başta asidoz olmak üzere birçok hastalığın oluşmasına neden olur. Bu çalışmada en önemli tespitlerden biri ise yetiştiricilerin büyük çoğunluğunun veya tamamına yakının bu hastalığ önlemek için en az bir defa dahi olsa yüksek oranda aşılatma oranının olmasıdır.

\section{SONUÇ}

Gıda güvenliği ve güvencesi insanlığın en temel problemleri arasındaki yerini gün geçtikçe daha derinden hissettirmektedir. Türkiye g1da üretimini stratejik bir ürün olarak belirlemeli, kısa orta ve uzun vadeli planlarını bu çerçevede oluşturmalıdır. Gıda üretiminde kendi kendine yeterli hale gelmek özellikle hayvansal ürünlerde bulunduğu sosyo-ekonomik özellikleri kullanarak net ithalatçı konumdan ihracatçı konuma gelmeyi gerçekleştirmelidir.

Bunun için küçükbaş hayvansal üretimin alınacak önlemler ile üreticiler açısından karlı bir yatırım olacak hale gelmesi ve bir anlamda gelecek nesiller için yatırım yapılabilecek cazip alan haline gelmesi için hem ekonomik hem de sosyo-kültürel önlemler alınmalıdır. Bu kırsal göçü de önleyecektir.

Yapılan saha çalışması sonuçlarına göre; ilçede koyun, keçi yetiştiriciliğinin geleneksel bir üretim alanı olma konumunu sürdürdüğü, üreticilerin eğitim düzeylerinin düşük olduğu belirlenmiştir. Üreticiler genel olarak orta yaş ve üzeri grupta yer aldıkları dolayısıyla da koyun keçi yetiştiriciliğini genç nesiller için cazip hale getirecek önlemlerin acilen alınması gerektiği anlaşılmıştır.

Eğitim seviyesindeki düşüklük bakım besleme de geleneksel yöntemlerin değiștirilmesini ve koruyucu hekimliği geri plana atmakta salgın hastalık ve zorunlu hallerin dişında hekimlik hizmetleri geri plana atılmaktadır. İşletmelerde bakım besleme yetersizliği ve vitamin mineral yetmezliğinin önemli verim kayıplarına ve gelir kaybına neden olduğu tespit edilmiş ve alınacak önlemler ile bu kayıpların azalması işletmelerde karlılık ve verimliliğin artmasına katkı sağlayacaktır.

Bölgede terörün azalması ve ortadan kalkması yayla ve göçer yetiştiriciliğin yaygınlaşmasına katkı sağlayacak ve sektör daha karlı hale gelecektir. Yapılan saha çalışması ile hayvan besleme konusunda yapılacak çok temel bilgilendirmeler ile (doğru vitamin premiks kullanımı, flushing, koruyucu aşılama vb) koyun 
keçi yetiştiriciliği daha karlı ve verimli hale gelebileceği açıkça anlaşılmıştır.

Mutki ilçesinde koyun keçi yetiştiriciliğinin alınacak önlemler ile gelişme potansiyeli vardır. Ancak yetiştiriciliğin geleneksel yöntemden rasyonel üretim biçimine geçirilmesi gerekir. Bunun için üreticilerin sosyo-ekonomik düzeylerine göre bilgilendirme eğitimi öncelikli olarak düşünülmeli uzun vade de ise alınacak destek ve teşvik önlemleri ile üreticilerin hem yetiștiricilik bilgi düzeyleri hem de genel eğitim seviyeleri artırılmalıdır. Çalışma bulguları mevcut şartlarda bile eğitim düzeyi ile bazı yetiştiricilik parametreleri arasında önemli ilişkilerin tespit edildiği göz ardı edilmemelidir.

Mikro düzeyde yetiştiricilerin bakım, besleme, sürü-işletme yönetimi konusunda bilgi düzeyleri ve alışkanlıklarını iyileştirebilecek projeler yapılmalıdır. Bu amaçla ulusal ve uluslararası fonlardan yararlanılmalıdır. Küçükbaş hayvansal üretimin üretim biçiminden kaynaklanan yorucu ve itici nitelikleri yapılacak reel iyileştirmeler ve önlemler ile genç kuşaklar için cazibeli hale getirilmelidir. Mutki ilçesinde koyun ve keçi yetiştiriciliği yapan işletmelerde özellikle etkili koruyucu hekimlik uygulamalarının işletme karlılık ve verimliliğini artıracağı açıktır. Küçükbaş hayvan yetiştiriciliğinin hayvansal üretime yönelik destek ve teșviklerin ötesinde bazı sosyal uygulamalar ile yaşam standartları yükseltilmeli, barınma iletişim, ulaşım, erken emeklilik vb uygulamalar ile yetiştiricilik cazip hale getirilmelidir. Unutulmamalıdır ki koyun keçi yetiştiriciliği özellikle dış satım ve uluslararası rekabet açısından ülkemiz ve bölge için bir avantaj ve öncelikli alandır. Bölgede koyun keçi yetiştiricilerine hayvansal üretime yönelik destek ve teșviklerin dışında bu işletmelerde işletme ölçeğini büyütebilecek uygulama ile ilişkilendirecek bir proje uygulamaya konulmalı ve orta vadede tüm işletmelerde hayvan sayısını kademli ve sürdürülebilir olarak artırmanın yolu aranmalıdır.

\section{BEYANNAMELER}

\section{Etik Onay1}

Bu çalışmanın Etik Kurul onayı Atatürk Üniversitesi Veteriner Fakültesi Etik Alt Kurul Başkanlığı tarafindan 20/12/2016 ve 2 nolu Kararı ile alınmıştır.

\section{Çıkar Çatışması}

Yazarlar, herhangi bir çıkar çatışması beyan etmemektedir.

\section{Yazar Katkıları}

Fikir, Kavram ve Tasarım: H İmik, S Yıldırım

Veri Toplama ve Analiz: S Y1ldırım

Makalenin Yazımı: S Yıldırım, H İmik

Eleştirel İnceleme: H İmik, A Günlü

\section{Veri kullanılabilirliği}

$\mathrm{Bu}$ çalışmanın bulgularını destekleyen veriler makul talep üzerine sorumlu yazardan temin edilebilir.

\section{KAYNAKLAR}

1. Türkiye İstatistik Kurumu (TÜIK). [İnternet]. [Erişim tarihi: 20 Haziran 2019] Erişim adresi: http://www.tuik.gov. tr/PreIstatistikTablo.do?istab id $=1568$

2. Türkiye İstatistik Kurumu (TÜİK). [İnternet]. [Erişim tarihi: 20 Haziran 2019] Erişim adresi: https://biruni.tuik.gov. tr/bolgeselistatistik/tabloOlustur.do

3. Günlü A. Buzağı Kayıpları ve buzağı hastalıklarının ekonomik önemi, Buzağı sağlığı ve yetiştiriciliği, TC KOP idaresi Başkanlığ1, Medisan, pp 139-144.

4. Sümbüloğlu K, Sümbüloğlu V. Biyoistatistik, Ankara, pp53-59 Hatipoğlu Yayıncılık 2013.

5. Gençyürek G. Bursa İli Uludağ Yöresinde Küçükbaş Hayvancilık Faaliyetleri. Sosyal Bilimler Enstitüsü, Coğrafya Anabilim Dalı. Yüksek Lisans Tezi, Çanakkale: Onsekiz Mart Üniversitesi. 2014.

6. Örnek H. Gaziantep İlinde Küçükbaş Hayvan Yetiştiriciliğinin Yapısal Özellikleri. Fen Bilimleri Enstitüsü, Zootekni Anabilim Dalı. Yüksek Lisans Tezi, Hatay: Mustafa Kemal Üniversitesi. 2018.

7. Acar M. Isparta İli Damızlık Koyun Keçi Yetiştiricileri Birliği Üyesi Keçicilik İşletmelerinin Mevcut Durumu ve Teknik Sorunları Üzerine Bir Araştırma. Fen Bilimleri Enstitüsü, Zootekni Anabilim Dalı. Yüksek Lisans Tezi, Isparta: Süleyman Demirel Üniversitesi. 2010.

8. Y1lmaz C. Hakkâri İli Yüksekova İlçesi Küçükbaş Hayvan Yetiştiriciliğinin Yapısal Durumu. . Fen Bilimleri Enstitüsü, Zootekni Anabilim Dalı. Yüksek Lisans Tezi, Van: Yüzüncü Y1l Üniversitesi. 2016.

9. Yıldız A. Van İli Merkez İlçede Küçükbaș Hayvancılık Faaliyetleri ve Genel Sorunlar. Fen Bilimleri Enstitüsü, Zootekni Anabilim Dalı. Yüksek Lisans Tezi, Van: Yüzüncü Y1l Üniversitesi. 2011.

10. Bilginturan S. Burdur ili Damızlık Koyun Keçi Yetiştiricileri Birliği Üyesi Keçicilik İşletmelerinin Yapısal Özellikleri ve Sorunları Üzerine Bir Araştırma. Süleyman Demirel Üniversitesi Ziraat Fakültesi Dergisi. 2008; p. 3(1):24-31. 